Section Editor

Mitchell S.V. Elkind, MD, MS

\section{Teaching NeuroImages: \\ Drug-induced parkinsonism with asymmetrical putaminal DaT binding}

Figure Brain SPECT and MRI
Claire Bridel, MD, PhD Valentina Garibotto, MD

Correspondence to Dr. Garibotto:

valentina.garibotto@hcuge.ch

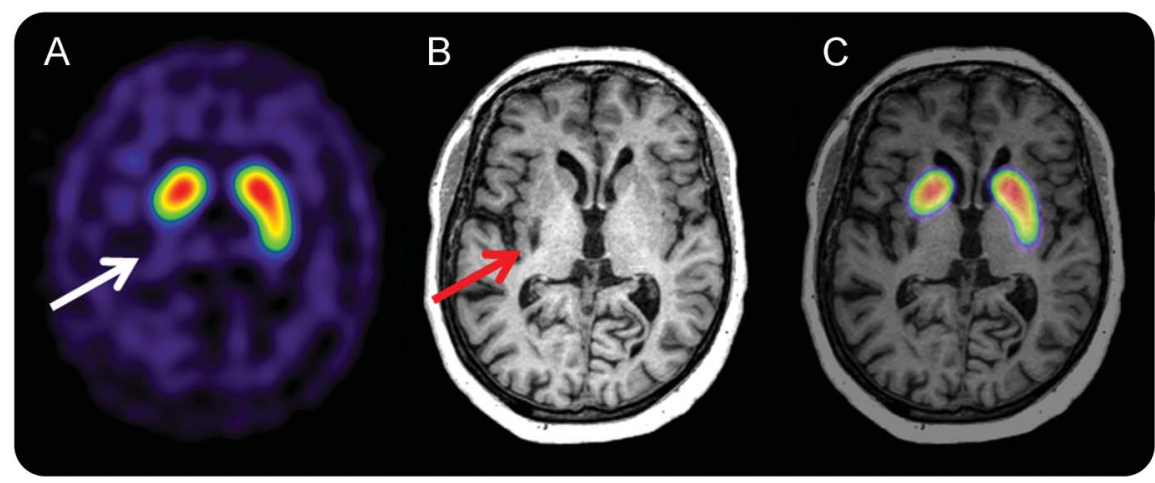

123/-loflupane SPECT imaging, a measure of dopamine transporters density, demonstrates right posterior putamen hypoactivity ( $A$, white arrow), a distribution typically observed in degenerative parkinsonism. This hypoactivity matches a T1 hypointensity on brain MRI (B, red arrow), consistent with ischemic sequela. (C) SPECT and MRI superposition.

A 64-year-old patient developed shuffling gait and postural instability over 8 months, in parallel to risperidone intake. Examination showed symmetric parkinsonian syndrome and mild left hemiparesis with spasticity, related to right middle cerebral artery stroke 10 years before. Within 1 month of risperdone withdrawal, parkinsonism disappeared, confirming drug-induced etiology. While degenerative parkinsonism is associated with reduction in striatal dopamine transporters binding in absence of structural lesions to basal ganglia, binding in drug-induced parkinsonism is normal. ${ }^{1}$ In our case, SPECT anomaly was incidental, related to the ischemic sequela (figure). ${ }^{2}$ This case highlights the importance of brain structural integrity for SPECT interpretation.

\section{AUTHOR CONTRIBUTIONS}

Claire Bridel: drafting/revising the manuscript, analysis or interpretation of data, accepts responsibility for conduct of research and final approval. Valentina Garibotto: drafting/revising the manuscript, analysis or interpretation of data, accepts responsibility for conduct of research and final approval, acquisition of data.

\section{STUDY FUNDING}

No targeted funding reported.

\section{DISCLOSURE}

The authors report no disclosures relevant to the manuscript. Go to Neurology.org for full disclosures.

\section{REFERENCES}

1. Marshall V, Grosset D. Role of dopamine transporter imaging in routine clinical practice. Mov Disord 2003:18:1415-1423.

2. Russmann H, Vingeroets F, Ghika J, Maeder P, Bogousslavsky J. Acute infarction limited to the lenticular nucleus: clinical, etiologic, and topographic features. Arch Neurol 2003;60:351-355.
Download teaching slides: Neurology.org
From the Department of Clinical Neurosciences, Division of Neurology (C.B.), and the Department of Radiology, Division of Nuclear Medicine and Molecular Imaging (V.G.), Geneva University and Geneva University Hospitals, Switzerland. 


\section{Neurology}

\section{Teaching NeuroImages: Drug-induced parkinsonism with asymmetrical putaminal DaT binding \\ Claire Bridel and Valentina Garibotto \\ Neurology 2015;84;e159 \\ DOI 10.1212/WNL.0000000000001590}

This information is current as of May 18, 2015

\section{Updated Information \& Services}

Supplementary Material

\section{References}

Subspecialty Collections

\section{Permissions \& Licensing}

Reprints including high resolution figures, can be found at: http://n.neurology.org/content/84/20/e159.full

Supplementary material can be found at: http://n.neurology.org/content/suppl/2015/05/16/WNL.0000000000001 590.DC1

This article cites 2 articles, 0 of which you can access for free at: http://n.neurology.org/content/84/20/e159.full\#ref-list-1

This article, along with others on similar topics, appears in the following collection(s):

Basal ganglia

http://n.neurology.org/cgi/collection/basal_ganglia MRI

http://n.neurology.org/cgi/collection/mri

Parkinson's disease/Parkinsonism

http://n.neurology.org/cgi/collection/parkinsons_disease_parkinsonism SPECT

http://n.neurology.org/cgi/collection/spect

Information about reproducing this article in parts (figures,tables) or in its entirety can be found online at:

http://www.neurology.org/about/about_the_journal\#permissions

Information about ordering reprints can be found online:

http://n.neurology.org/subscribers/advertise

Neurology ${ }^{\circledR}$ is the official journal of the American Academy of Neurology. Published continuously since 1951, it is now a weekly with 48 issues per year. Copyright () 2015 American Academy of Neurology. All rights reserved. Print ISSN: 0028-3878. Online ISSN: 1526-632X.

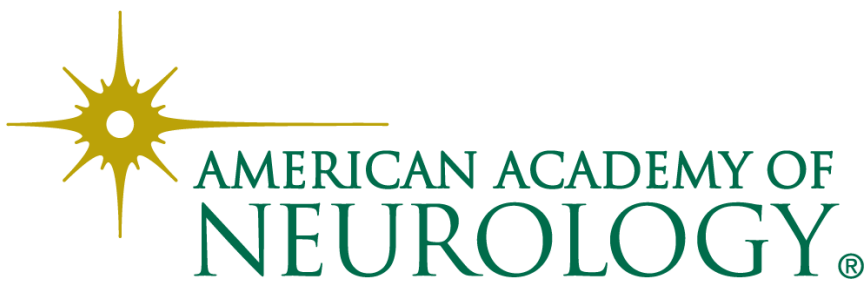

